\title{
Metabolism of the Extracellular Matrix in Bronchial Asthma (Review)
}

DOI: $10.17691 / \mathrm{stm} 2018.10 .4 .25$

Received February 3, 2018

T1. Eliseeva, MD, DSc, Professor, Department of Hospital Pediatrics";

E.V. Tush, MD, PhD, Associate Professor, Department of Hospital Pediatrics ${ }^{1}$;

S.Y. Krasilnikova, Assistant, Department of ENT Diseases";

S.V. Kuznetsova, MD, DSe, Associate Professor, Department of Pathophysiology';

R.A. Larin, Otorhinolaryngologist, Head of the Department of Otolaryngology2;

N.1. Kubysheva, DSC, Senior Researcher, Medical Informatics Research Laboratory

of the Higher School of Information Technologies and Information Systems;

O.V. Khaletskaya, MD, DSc, Professor, Head of the Department of Hospital Pediatrics ${ }^{1}$;

T.E. Potemina, MD, DSc, Professor, Head of the Department of Pathophysiology';

S.V. Ryazantsev, MD, DSc, Professor, Deputy Director for Research and Coordination Work'

S.K. Ignatov, DSc, Professor, Department of Physical Chemistry ${ }^{5}$

${ }^{1}$ Privolzhsky Research Medical University, 10/1 Minin and Pozharsky Square, Nizhny Novgorod, 603005, Russia;

${ }^{2}$ N.A. Semashko Nizhny Novgorod Regional Hospital, 190 Rodionova St., Nizhny Novgorod, 603126,

Russia;

${ }^{3}$ Kazan Federal University, 18 Kremlyovskaya St., Kazan, Republic of Tatarstan, 420008, Russia;

${ }^{4}$ Saint-Petersburg Institute of Ear, Nose, Throat, and Speech of the Ministry of Health of the Russian Federation,

9 Bronnitskaya St., Saint Petersburg, 190013, Russia;

${ }^{5}$ National Research Lobachevsky State University of Nizhny Novgorod, 23 Prospekt Gagarina,

Nizhny Novgorod, 603950, Russia

Bronchial asthma is associated with upper airway (UA) disorders, primarily with allergic rhinitis, which, in turn, occurs in combination with other UA conditions, including hyperplasia of the nasal mucosa. Chronic rhinosinusitis, if confirmed, is a predictor of asthma severity.

The pathogenesis of these diseases includes the remodeling (restructuring) of the extracellular matrix and the adjacent UA structures, which is associated with further worsening of the diseases and their resistance to therapy. It is known that remodeling of the lower respiratory tract in bronchial asthma is characterized by epithelial desquamation, hyperplasia of goblet cells, thickening of the basement membrane, fibrosis of the subepithelium, hyperplasia of smooth muscles of the respiratory tract, and increased angiogenesis. At the same time, the UA remodeling in patients with asthma is still poorly understood; the data are still limited and often contradict each other. With isolated allergic rhinitis, the remodeling process is not very much pronounced and is limited, apparently, to a basement membrane thickening. In chronic rhinosinusitis, the UA remodeling manifests by epithelial hyperplasia and an increased sedimentation and degradation of the matrix along with the accumulation of plasma proteins.

Despite recent extensive studies, the cellular and molecular mechanisms involved in the respiratory tract remodeling remain largely undetermined, which necessitates further research into these processes. The review addresses several aspects of neuro-humoral control of the extracellular matrix metabolism and the associated remodeling of the upper and lower airway in patients with asthma.

Key words: bronchial asthma; allergic rhinitis; chronic rhinosinusitis; extracellular matrix; remodeling.

\section{Introduction}

Extracellular matrix (ECM) is a collective name for the extracellular tissue structures (basement membranes, interstitial matrix) that provide mechanical support for cells, perform signal conduction, participate in metabolism and transport, mediate the cell-cell contacts and cell locomotion. Components of the fluid connective tissues — blood plasma and lymphatic fluid — that mediate gas exchange and maintain homeostasis [1] are also attributed to the ECM.

Previously, ECM was considered an inert structure. Recent studies demonstrate though that ECM is a biologically active medium, crucial for the functioning of organs and systems, both in normal conditions and in disease [2]. Changes in ECM of the respiratory tract and/or lung parenchyma are considered key elements of bronchial asthma (BA) and the concomitant diseases of

Corresponding author: Tatiana I. Eliseeva, e-mail: Eliseevati@yandex.ru 
the upper airway (UA) [3-5]. It has been lately discussed whether changes in ECM are a consequence of these diseases or whether they are active elements of the pathogenesis that determines the clinical picture of the disease [6]. The most recent data suggest that changes in the composition and quality of ECM proteins may alter the functional characteristics of cells associated with the ECM [7].

Expanding the knowledge about the ECM in patients with $\mathrm{BA}$ and the associated UA disorders will contribute to a better understanding of respiratory chronic diseases and will help in a search for new approaches to their treatment [8].

\section{Structure and function of the extracellular matrix}

Extracellular matrix is a complex and dynamic structure that provides a mechanical framework for cells located inside it. ECM consists of a large number of macromolecules, mainly proteins and glycoproteins; their composition and structure are organ-specific [9].

There are two types of ECM: the first is represented by the basement membrane (BM), which lies directly beneath the epithelial and endothelial cells, and the second is the interstitial matrix of connective tissue surrounding the cells.

The BM functions as a supporting structure consisting of orderly arranged molecules, which adhere to endothelial and/or epithelial cells and protect them against biochemical and biophysical stresses [10]. The barrier function of the BM enforces the function of mucous membranes in the respiratory, gastrointestinal and urinary systems [9]. In addition, BM (or basal plates) represents a supporting structure for muscle and adipose cells, neurons and the Schwann cells of peripheral nerves [11]. These "leaf-like" layers appear at an early stage of embryogenesis; they separate tissues, function as macromolecular filters, and provide sites for cell adhesion [9]. By mediating the contacts between the epithelial membrane receptors and the BM proteins, BMs participate in cell arrangement and differentiation. In this respect, of particular importance are integrins transmembrane heterodimeric cell receptors that interact with the ECM and transmit signals to the cells. On the basal side of the epithelial cells, hemidesmosomes BM protein binding receptors - are expressed [9].

The BM consist mainly of type IV, XV, XVIII collagens, laminins, glycoproteins, and proteoglycans, which separate the epithelium or endothelium from the surrounding stroma [9] (Table 1). Laminins provide attachment of epithelial cells to BM and, in conjunction with type IV collagen and other components of BM, ensure its stability. The laminin networks are noncovalent and, therefore, more active than the collagen networks [12]. Both networks are linked via nidogen, which plays a role in their structure stabilization [13-17].

The interstitial matrix is also tissue-specific and includes, as a rule, a large number of fibrous proteins (collagen, elastin), fibronectin and proteoglycans, which are interconnected with other molecules and assembled into complex fibrillary networks [1]. The interstitial component of the ECM is needed for structural stability of tissues, cell migration, their proliferation and adhesion; in addition, it takes part in the control over synthesis of inflammatory mediators and the regulation of water balance $[9,18]$.

Table 1

Major structural components of the extracellular matrix ([1, 9] with additions)

\begin{tabular}{|c|c|c|}
\hline \multicolumn{3}{|c|}{ The most common types of collagen } \\
\hline Class & Type & Description \\
\hline Fibrillary collagens & I, II, III, V, XI, XXIV, XXVII & $\begin{array}{l}\text { Localized largely in tissues with a fibrous ECM, such } \\
\text { as skin, bones, tendons, and ligaments }\end{array}$ \\
\hline Network-forming collagens & IV & $\begin{array}{l}\text { Localized in the basement membranes (among others). } \\
\text { Have a mesh structure associated with laminins and } \\
\text { other proteins of the basement membrane }\end{array}$ \\
\hline Short-chain collagens & VIII, X & Involved in regulation \\
\hline $\begin{array}{l}\text { Fibril-associated collagens with intermittent } \\
\text { triple helix }\end{array}$ & $\begin{array}{l}I X, X I I, X I V, X V I, X I X, X X \\
\text { XXI, XXII }\end{array}$ & $\begin{array}{l}\text { Molecular bridges linked to type I (XII, XVI, XIX, XXI) } \\
\text { collagen fibrils and type II (IX, XVI, XIX) collagen fibrils }\end{array}$ \\
\hline $\begin{array}{l}\text { Membrane-associated (transmembrane) collagens } \\
\text { with intermittent triple helix }\end{array}$ & XIII, XVII, XXIII, XXV/CLAC-P & $\begin{array}{l}\text { Cell membrane-associated molecules with } \\
\text { transmembrane and intracellular domains }\end{array}$ \\
\hline Long-chain collagens & VII & $\begin{array}{l}\text { Anchor fibrils } \\
\text { Collagen-containing anchor fibrils, mainly associated } \\
\text { with basement membranes }\end{array}$ \\
\hline Collagen shaped as filaments-beads & VI & Soft tissues, cartilages \\
\hline Multiplexin & $\mathrm{XV}, \mathrm{XVIII}$ & $\begin{array}{l}\text { Localized mainly in endotheliocytes. Multiple interrupted } \\
\text { triple helical domains containing chondroitin sulfate } \\
\text { and glycosaminoglycan heparin sulfate }\end{array}$ \\
\hline
\end{tabular}




\section{REVIEWS}

End of the Table 1

\begin{tabular}{|c|c|c|}
\hline \multicolumn{3}{|c|}{ Major proteoglycans of the extracellular matrix } \\
\hline Classes & Groups (types) & Molecules \\
\hline Hyaluronan & - & - \\
\hline \multirow[t]{2}{*}{ Extracellular proteoglycans } & Hyalectans & $\begin{array}{l}\text { Aggrecan } \\
\text { Versican } \\
\text { Neurocan } \\
\text { Brevican }\end{array}$ \\
\hline & $\begin{array}{l}\text { Small leucine-enriched } \\
\text { proteoglycans }\end{array}$ & $\begin{array}{l}\text { Decorin } \\
\text { Biglycan } \\
\text { Fibromodulin } \\
\text { Lumican }\end{array}$ \\
\hline $\begin{array}{l}\text { Pericellular proteoglycans/basement membrane } \\
\text { proteoglycans }\end{array}$ & $\begin{array}{l}\text { Perlecan } \\
\text { Agrin } \\
\text { Bamacan }\end{array}$ & - \\
\hline Proteoglycans embedded in the cell membrane & $\begin{array}{l}\text { Syndecans } \\
\text { Glypicans } \\
\text { Chondroitin sulfate } 4 \text { proteoglycan } \\
\text { Beta-glycans } \\
\text { Phosphacans }\end{array}$ & - \\
\hline Intracellular proteoglycans & - & - \\
\hline \multicolumn{3}{|c|}{ Specialized non-collagen proteins of the extracellular matrix } \\
\hline Protein & Locations & Notes \\
\hline Elastin and elastin-associated proteins & $\begin{array}{l}\text { Arteries, connective tissue, } \\
\text { respiratory system, lungs, skin, } \\
\text { bladder }\end{array}$ & $\begin{array}{l}\text { Provide structural integrity along with reversible } \\
\text { extensibility and deformability }\end{array}$ \\
\hline Fibronectin & Blood, connective tissue & - \\
\hline Laminins & Basement membrane & - \\
\hline Matrikines & Connective tissue & $\begin{array}{l}\text { Disulfide-linked proteins involved in the formation } \\
\text { of filaments }\end{array}$ \\
\hline Fibrinogen & Blood & $\begin{array}{l}\text { Soluble glycoprotein, a component of the blood } \\
\text { coagulation system }\end{array}$ \\
\hline Fibrillin & $\begin{array}{l}\text { Connective tissue, cardiovascular } \\
\text { tissue }\end{array}$ & $\begin{array}{l}\text { The predominant component of microfibrils; creates } \\
\text { a shell around elastin of the elastic fibers }\end{array}$ \\
\hline Fibulins & $\begin{array}{l}\text { Basement membranes, blood } \\
\text { vessels, blood }\end{array}$ & Calcium binding glycoprotein \\
\hline Netrins & Basement membranes & $\begin{array}{l}\text { Laminin-bound proteins that are involved in axon control } \\
\text { and vascularization of tissues, including the lungs }\end{array}$ \\
\hline Osteopontin & Various tissues & Bone mineralization, cell adhesion and cell attachment \\
\hline Tenascins & Connective tissue & $\begin{array}{l}\text { Glycoproteins that are involved in inflammation } \\
\text { and fibrosis }\end{array}$ \\
\hline Vitronectin & Blood & $\begin{array}{l}\text { Adhesive glycoprotein associated with coagulation } \\
\text { and wound healing }\end{array}$ \\
\hline
\end{tabular}

By now, 28 basic types of collagen have been described; they differ from each other by the amino acid sequence, as well as by the mode of hydroxylation and glycosylation. The common feature of all these collagens is the existence of triple helix domains, which are considered part of the ECM. More than $90 \%$ of total collagen of higher organisms is represented by collagens of types I, II, III, and IV.

In addition to collagens, there are many other proteins containing triple helix domains [1]. Nevertheless, those are not classified as collagens, but as collagen-like proteins. Examples of such proteins are adiponectin, collectins, and ficolins, the terminal structure of acetylcholinesterase, etc. These proteins play both a structural and a regulatory role [19].

Cells populating the ECM interact with this macromolecular network through their surface receptors, such as integrins, proteoglycans (localized on the cell 
surface), the hyaluronan CD44 receptor and other molecules [20, 21]. This way the cells communicate with the ECM; these signals largely determine their function and behavior. Various growth factors, cytokines, and chemokines bound to specific ECM molecule are found within the ECM; eventually, these regulatory molecules are released and activated under specific physiological conditions. Changes in the composition and structure of individual ECM components affect the structural and functional parameters of the entire network, as well as the numerous cellular elements associated with ECM $[22,23]$. Notably, all the ECM cells, including epithelial and endothelial, immune cells, fibroblasts, and smooth muscle cells participate in the synthesis and secretion of matrix macromolecules, thus maintaining the ECM structure and function. The term "matrikines" has been proposed for the bioactive ECM fragments that modulate various physiological processes. It has been shown that some matrikines - metabolites of ECM components are involved in the mechanism of inflammation and immune homeostasis [24, 25].

There are reports on syndromes and diseases caused by abnormalities in the synthesis and metabolism of ECM components; those are currently considered as potential targets for pharmacological therapy [26].

\section{Structure of the extracellular matrix in the respiratory system}

Respiratory organs perform two vital physiological functions: passive gas exchange (alveolar respiration) and immune protection against exogenous antigens (by virtue of the epithelial barrier). The ECM of the respiratory system is saturated with elastin. The ECM structure often changes in response to environmental factors detrimental to the airway epithelium, including chronic exposure to inhaled allergens, cigarette smoke, pollutants, and infections [27]. Damaged epithelial cells can provoke a specific ECM remodeling, which, in turn, affects the epithelial cells themselves [28].

The respiratory system has a unique composition; the ECM maintains permeability of the airway, and gas exchange in the lung parenchyma. In the proximal airway segments, the ECM contains a large amount of collagens, laminins, and proteoglycans [29]. In the alveoli, type I epithelium prevails; its cell walls almost merge with endothelial cells of proximal capillaries, creating an ultrathin elastin-dominated ECM to ensure effective gas exchange [29].

The nose and paranasal sinuses provide the conditioning of the inhaled air, and the ECM and the epithelial UA lining protect the lower airways from antigens and pollutants [30]. The UA epithelium has a predominantly pseudo-layered columnar structure, and the supporting connective tissue is largely loose. In BA and comorbidities, abnormalities of the UA extracellular matrix manifest in different ways (from fibrosis to severe edema), which is due to extensive vascularization of the UA [31].

\section{Metabolism of the extracellular matrix}

Recent studies show that ECM is a highly active tissue that is constantly being reconstructed, thus responding to the needs of growth and repair [32].

In the body, ECM undergoes continuous degradation mediated by special enzymes, accompanied by simultaneous synthesis and restructuring of matrix components. Changes in the ECM affect the surrounding cells so to regulate their proliferation, migration, or differentiation [33]. Normally, ECM homeostasis is characterized by an optimal balance between the formation, secretion, alteration, and degradation of the matrix [34]. The local degradation of ECM is a prerequisite for cell migration and proliferation.

The restructuring of the ECM is called "remodeling". This term refers to structural and geometric changes in the ECM and has both a physiological and a pathogenetic meaning. In a healthy person, remodeling occurs from the birth through the maturity as an adaptive response to the body growth. Abnormal remodeling of ECM may reflect a disease, for example, chronic obstructive pulmonary diseases [33].

The proteolytic degradation of ECM components is mediated by enzymes, including matrix metalloproteinases (MMPs); disintegrins and metalloproteinases (ADAMs a disintegrin-like and metalloproteinase domain); ADAMs with thrombospondin motifs (ADAMTS - ADAMs with thrombospondin type I motifs); enzymes of the meprin family; serine/threonine proteases (elastase, matriptase, urokinase activator and tissue plasminogen); cysteine proteases; aspartate proteases [35-37] and other enzymes [38].

The enzymes of the ADAMs group mainly cleave the transmembrane protein ectodomains associated with the cell membrane. This is accompanied by a release of cytokines, growth factors, receptor and adhesion activation $[33,39]$.

The meprins are proteases that cleave ECM proteins, such as collagen IV, nidogen and fibronectin [40]. Meprins can also contribute to the formation of true collagen molecules by cleaving procollagen I, which is then assembled into collagen fibrils [41]. Indirectly, meprins control ECM remodeling by activating other metalloproteinases [33].

Excessive degradation of ECM leads to tissue destruction. At the same time, excessive production of ECM components and their precipitation, which occur in response to severe tissue damage, can cause fibrosis in the absence of adequate degradation of ECM components [14].

\section{Remodeling of the extracellular matrix in bronchial asthma}

Airway remodeling in BA can be defined as an advancing pathological reorganization of their cellular and molecular structure. The onset and progression of 
the structural changes remain the subject of discussion; nevertheless, the negative impact of the airway remodeling on the respiratory system is now generally recognized [42].

In $\mathrm{BA}$, the airway remodeling likely results from the bronchial tree inflammation caused, among other factors, by exposure of sensitized patients to allergens [43]. The airway remodeling in asthma can be caused by a mechanical stress or triggered by earlier life events $[44,45]$.

Nevertheless, the linear model suggesting that an environmental sensitization leads to allergic inflammation (mediated by Th2 cells) and subsequent airway remodeling, has been questioned for asthma in pediatric patients. Bronchial biopsies in children with asthma show pronounced remodeling at an early stage of the disease, thus implicating the allergic component of asthma rather than chronic airway inflammation [46, 47]. Elliot et al. demonstrated that the mechanisms of airway remodeling in BA could be associated both with the inflammation and/or with non-inflammation processes [48]. There is a debate about whether the inflammation precedes the remodeling and whether it can be associated with primary anomalies (e.g., atopy) of the epithelial recovery [49], or the remodeling does not depend on inflammation and can occur before clinical manifestations of BA [50].

Remodeling of the airways in asthma includes largescale structural changes, which lead to a narrowing of the

\section{Table 2}

Participation of various cell types in the pathological airway remodeling in bronchial asthma ([60] with additions)

\begin{tabular}{|c|c|}
\hline Cell types & Role in the airway remodeling \\
\hline \multirow[t]{8}{*}{ Epithelial cells } & Desquamation of epithelial cells \\
\hline & Affects mucus secretion \\
\hline & Subepithelial fibrosis \\
\hline & Hyperplasia of the mucous glands \\
\hline & $\begin{array}{l}\text { Stimulating smooth muscle cell proliferation in the bronchi } \\
\text { through the release of growth factors }\end{array}$ \\
\hline & Recruitment of pro-inflammatory cells \\
\hline & Accelerates sediment deposition in the extracellular matrix \\
\hline & Stimulates angiogenesis and neo-angiogenesis \\
\hline \multirow[t]{4}{*}{$\begin{array}{l}\text { Bronchial smooth } \\
\text { muscle cells }\end{array}$} & $\begin{array}{l}\text { Bronchial smooth muscle hypertrophy that narrows } \\
\text { the airway lumen }\end{array}$ \\
\hline & $\begin{array}{l}\text { Migration of bronchial smooth muscle cells } \\
\text { and their invasion into the epithelium }\end{array}$ \\
\hline & $\begin{array}{l}\text { Transformation of the bronchial smooth muscles } \\
\text { into the "synthetic phenotype": results in excessive } \\
\text { secretion of transforming growth factor beta (TGF- } \beta \text { ), } \\
\text { chemokines, and extracellular matrix components }\end{array}$ \\
\hline & $\begin{array}{l}\text { Interaction with immune and other cells mediated by cell } \\
\text { adhesion molecules }\end{array}$ \\
\hline \multirow[t]{2}{*}{ Fibroblasts } & $\begin{array}{l}\text { Differentiation into myofibroblasts, secretion of extracellular } \\
\text { matrix components }\end{array}$ \\
\hline & Accumulating in the subepithelial layer \\
\hline
\end{tabular}

airways, increasing their resistance and retaining mucus in the bronchial lumen. Remodeling of the airways in asthma also includes thickening of their walls, hyperplasia and hypertrophy of the bronchial smooth muscles (BSM), edema, subepithelial fibrosis, quantitative and qualitative changes in the ECM, remodeling of the ECM subepithelial space, loss of the barrier function of the BM, accumulation of immune cells and fibroblasts, angiogenesis, epithelial metaplasia, loss of cilia, and mucus hypersecretion [51]. The deposition of ECM in the subepithelial area may play an important role in modulating the structure and function of the epithelial cells and fibroblasts, since these deposits are in a close contact with the epithelial cells and, moreover, they all form a functional epithelialmesenchymal-trophic unit (EMTU).

In $\mathrm{BA}$, the characteristic feature of the airway remodeling and structural changes in the ECM is the BM thickening described by Huber and Koessler as early as in 1922 [52]. At present, it is known that the BM thickening in patients with asthma is accompanied by the accumulation of collagens of types I, III, IV, and fibronectin [5]. For example, in healthy adults, the thickness of BM reticular plate is $5-6 \mu \mathrm{m}$, while in patients with chronic BA it is $9 \mu \mathrm{m}$ [27].

In asthma, ECM structural abnormalities are observed in all parts of the respiratory system (central respiratory tract, bronchial smooth muscles, distal parenchyma, and blood vessels). Manifestations of ECM remodeling depend on the severity of asthma, the degree of disease control, the patient's age, and the pharmacotherapy [27].

Structural changes in ECM in asthma can be accompanied by a loss of some elastin fibers, which, coupled with a gradual decrease in lung function, can lead to a loss of the airway elasticity and, consequently, to the formation of air traps in the lungs [53].

Poon et al. [54] suggested that the angiogenesis and neovascularization of the mucous membranes are key factors in the airway remodeling in severe asthma. It was also demonstrated that the deposition of proteoglycans or collagen in the airway walls can contribute to bronchial hyperreactivity $[55,56]$.

An important role in the initiation of ECM rearrangement is played by the epithelium [57] (Table 2). For example, in asthma, repeated damage to epithelial cells by exogenous antigens and pollutants (in combination with immune factors) contributes to recurrent epithelium desquamation. This leads to permanent activation of the EMTU to maintain reparative processes that may be accompanied by prolonged and progressive remodeling of the airways $[58,59]$.

Another effector of the airway remodeling in asthma is the BSM, which (in patients with BA) actively secretes ECM components, cytokines and growth factors. BSM itself is linked to the ECM structure and thereby able to increase its contractile 
potential under ECM remodeling caused by airway inflammation [61, 62]. A BSM mass gain in combination with a BM thickening results in a narrowing of the airway lumen $[42,51]$.

It was found [63] that bronchoconstriction alone, without an inflammation, could induce airway remodeling in patients with BA. In this regard, it is an assumed that the mechanical forces developing in the airway walls during bronchoconstriction were those that triggered the remodeling [64].

It has been experimentally demonstrated [65] that the inflammation correlates with the increase in BSM contractility; the effect may be mediated by proinflammatory cytokines such as tumor necrosis factor. This process also involves an increase in the number of contractile units (active actin + myosin complexes). As a feedback, signals from the altered BSM can induce both the remodeling and the inflammation $[66,67]$. It is likely that both the inflammation and the remodeling can develop rapidly if caused by a viral infection, exposure to allergens, or even by excessive BSM contraction [63, 68]. All this underscores the need for additional research into the airway remodeling [51].

Fibroblasts and myofibroblasts contribute to the process of remodeling by excessively secreting ECM components. In addition to increasing the airway wall thickness, ECM components can modulate cell proliferation and migration. There is evidence [69] that increased expression of hyaluronic synthase 2 in myofibroblasts and smooth muscle cells leads to an increase in airway fibrosis. Thus, it is quite possible that the accumulation of hyaluronan participates in the airway wall thickening in asthma via this pathophysiological mechanism.

It is known that airway remodeling reduces the efficacy of bronchodilators [5, 32-34]. A correlation was established between the degree of airway remodeling and the severity of asthma, but the clinical implications of this relation are not fully understood [35, 70]. The insufficient knowledge impedes the development of pharmacotherapy targeting the asthma manifestations associated with the airway remodeling. Thus, it is important to assess the current therapeutic strategies in asthma for their abilities to counteract the pathological airway remodeling [51].

Airway remodeling can also be observed in clinical situations that are not accompanied by pronounced BA symptoms; for example, in allergic rhinitis or in elite athletes [71]

Possible adverse effects of airway remodeling in asthma include a reduction in the lung function, an irreversible airway obstruction, a decrease in the airway distensibility and the reaction to bronchodilators, a persistent hyper-reactivity, a decrease in the BSM ability to relax, a decrease the lung elasticity, and an increase in the BSM contractility caused by its hypertrophy [7274]. There are also positive consequences of the airway remodeling in asthma: for example, the airways become better protected against a bronchospasm due to the increased rigidity of their walls [75].

\section{Metabolism of the extracellular matrix in asthma patients of various ages}

The updated evidence suggests that the most of the airway remodeling in BA occurs before the onset of clinical symptoms or at an early age [76-78]. Thus, according to biopsy data, in preschool children with wheezing, the BSM and the reticular layer of the BM are thickened [79]. Owens et al. [80] showed that a decrease in the lung function in infancy was a predictor of asthma in young adults, indicating the likelihood of a very early (possibly intrauterine) structural change in the airways. It is assumed that the remodeling of BSM and the reticular layer of BM is possible at early stages of asthma and may be independent of a concomitant inflammation [76]. Age-dependent changes in the lung elasticity are also important determinants of the lung function; however, these changes are yet to be characterized in detail [3, 81, 82].

\section{Neurohumoral regulation of metabolism of the extracellular matrix in asthma and related diseases of the upper airway}

ECM metabolism and remodeling processes are controlled by neuroendocrine signals; studies on this mechanism are currently under way. Particular attention is paid to the effect of glucocorticoids on the process of remodeling because these agents are commonly used in the anti-inflammatory treatment of asthma and associated UA diseases.

It is well documented that inhaled glucocorticoids help restore the integrity of the epithelium, prevent vascular changes and the deposition of ECM components of in the airways. The glucocorticoids can affect the ECM through various mechanisms, including the effect on the genes encoding for ECM components [83, 84].

In recent years, close attention has been paid to the relationship between the nutritional status of patients and the course of asthma and associated UA diseases. We previously [85-87] showed that the severity of asthma is associated with the physical body development and nutritional status of patients. In this regard, it is also of great interest to assess the effect on the ECM of hormones regulating the energy exchange and adipose tissue metabolism. Williams et al. [81] found that the synthesis of metalloproteinases by fibroblasts is controlled by leptin. The stimulation of fibroblast by leptin can change the metabolism of ECM components, including fibrillary collagens. Zhang et al. [88] showed that leptin reduced the expression of matrix metalloproteinases 2 and 9 that catalyze the degradation of collagen, and simultaneously increased the production of the inhibitor of metalloproteinases 1 and collagens I and IV. These studies indicate that in 
the presence of leptin, the collagen synthesis dominates over its degradation.

In the experiment, adiponectin showed the exact opposite effect (increased expression of matrix metalloproteinases 2 and 9, and a decrease in TIMP1 protein and collagens), but its effect manifested only in the presence of leptin. Notably, the effect of leptin on the ECM is not only a direct interaction with the synthesis of structural components, but it is also mediated by the nervous system. Leptin dilates the airways by reacting with the $M 3$ receptors on the smooth muscles, regardless of inflammation in the respiratory tract, and thus modulates the autonomic control of the airways [89].

It has been demonstrated that a thyroid function insufficiency leads to excessive accumulation of hyaluronic acid in the ECM and also the development of myxedema [89]. The effect of the T3 hormone, like that of hydrocortisone, involves an inhibition of the hyaluronan synthesis; however, these two hormones may act through different pathways: 1) decreasing the synthesis of hyaluronan; 2) enhancing its catabolism, mediated by hyaluronidase. The effect of T3 is probably carried out through a decrease in the production of hyaluronate synthase 2. It should be noted that T3 does not affect the synthesis of collagen or chondroitin sulfate [90].

The surface receptor for iodothyronines is represented by $\alpha \mathrm{V} \beta 3$ integrin, which is a heterodimer that interacts with a large number of ECM proteins. Thyroid hormones, by binding to $\alpha \mathrm{V} \beta 3$, modify the expression of the vascular endothelial growth factor, promote angiogenesis, cell proliferation and cell migration [91].

As mentioned earlier, BSM cells are actively involved in ECM remodeling. The BSM involvement is thought to be controlled by the paracrine system. This mechanism where the BSM contractility is regulated by distant organs can help understand the pathogenesis and heterogeneity of asthma [59, 92]. The effects of hormones on the BSM are multidirectional. Thus, the activation of the BSM leptin receptor inhibits the proliferation and migration of BSM due to stimulation of prostaglandin E2 secretion [93]. A negative correlation has been found between the BSM mass and the serum level of vitamin $D$ in children with severe asthma resistant to therapy [94].

Insulin stimulates BSM hyper-contractility, possibly due to an increase in the free insulin-like growth factor, which is associated with BSM proliferation [95].

Sex steroids have a dual effect on ECM and BSM in patients with BA. Thus, high doses of estrogen increase the contractility of BSM ex vivo and reduce the lung function in vivo, while the estrogen replacement therapy reduces the airway reactivity and improves the lung function [96, 97].

Androgens are able to relax contracted BSM and potentiate the relaxing effect of $\beta 2$-agonists, which suggests their overall bronchodilation effect $[98,99]$. On the other hand, in the same preparations of BSM and at the same concentrations, androgens potentiate the contractile response to the spasmogen [99].

Inter-hormonal interactions and their impact on the $\mathrm{ECM}$ are also of considerable interest. In experiments of Ishida-Takahashi et al. [100], glucocorticoids inhibited the effects of leptin-mediated by the transcription factor pSTAT3. STAT3 is a signaling protein and a transcription activator from the STAT protein family, which is encoded by the human STAT3 gene. STAT3 is one of the intermediary proteins participating in the cell's response to signals via interleukin receptors and growth factors.

Neuro-regulation of ECM in patients with BA is the best studied in terms of cholinergic receptors. Stimulation of muscarinic receptors leads to proliferation and remodeling of BSM, proliferation of human lung fibroblasts, synthesis of collagen and matrix metalloproteinases 1 and 2 [101-104].

The muscarinic effects on the ECM are expressed by enhancing the contractile potential of human BSM cells [104]. A few recent reports described the effects of the M-choline blocker tiotropium bromide, a prolonged action drug [105]. Tiotropium bromide inhibits the remodeling of the bronchial wall, mitigates the wall thickening, the mucous gland hypertrophy, and the smooth muscle hyper-reactivity, and also reduces the level of Th2 cytokines and pulmonary eosinophilia caused by an allergen [106]. Part of this pharmacological activity of tiotropium is the inhibition of TGF- $\beta$-induced expression of metalloproteinases in human lung fibroblasts [107]. Tiotropium also inhibits the increased peribronchial collagen deposition in a model of chronic swine flu [108].

\section{Remodeling of the upper airway in patients with bronchial asthma}

Between 80 and $100 \%$ of patients with atopic asthma were also diagnosed with concomitant allergic rhinitis, which necessitated a closer look at their UA [109-113]. Recent studies demonstrate that the inflammation processes in the mucous membrane of the upper and lower airways in patients with asthma are identical and likely associated with the Th2-dependent mechanism $[114,115]$.

Assuming the remodeling is caused by inflammation, there must be detectable structural changes in the UA of patients with asthma due to the persistent inflammation caused by allergic rhinitis. However, no clear evidence of any rhinitis-induced remodeling has been provided in the literature [5].

Both in seasonal and year-round allergic rhinitis, biopsy specimens of the nasal mucosa (taken within first hours after exposure to significant allergens) showed an increased thickness of BM as compared to that in healthy subjects. However, $24 \mathrm{~h}$ after the exposure, despite the influx of eosinophils, no further BM thickening occurred $[116,117]$. Apparently, remodeling of UA is not a key feature of the immunopathogenesis of allergic rhinitis in patients with asthma. 
According to our earlier studies, isolated allergic rhinitis occurs only in part of children with asthma [112, 113]. In most of these patients, we found a combination of rhinitis and other UA disorders, including abnormal changes in the intranasal structures and hypertrophy of the pharyngeal tonsil. In some adolescent patients, there were hypertrophic changes in the nasal mucosa, which might indicate a possible debut of polyposis/ rhinosinusitis [110, 111, 118].

It is known that chronic rhinosinusitis (CRS) and BA are closely related, especially in adult patients [119, $120]$. CRS is a broad term for a group of heterogeneous inflammatory diseases - it is classified into CRS with or without nasal polyps [117, 121]. Up to $14 \%$ of patients with CRS-associated polyps and patients with aspirininduced respiratory diseases were also diagnosed with severe asthma [120,122].

Unlike allergic rhinitis, tissue remodeling in CRS is a hallmark of this condition. In CRS with polyps, the epithelial cells of the nasal mucosa degrade; under this condition, the excess mucus accumulation can be explained by hyperplasia of the mucous glands and hypersecretion of mucin [123, 124]. The BM thickening reflects the severity and duration of the disease and the concomitant asthma, which, apparently, does not depend on the degree of eosinophilic inflammation [125, 126].

The degradation of ECM is a key pathological change in CRS with polyps; in addition, there are changes in the tissue architecture and growth, including the occurrence of pseudocysts (Figures 1,2).

By now, the available descriptive studies have not yet provided a detailed understanding of ECM remodeling in patients with CRS [5]. The mucosa ECM remodeling is not a characteristic feature of allergic rhinitis, except for some thickening of BM. In CRS with polyps and in asthma, the epithelial cells look damaged and the goblet cells show hyperplasia. In both cases, EMTU activation

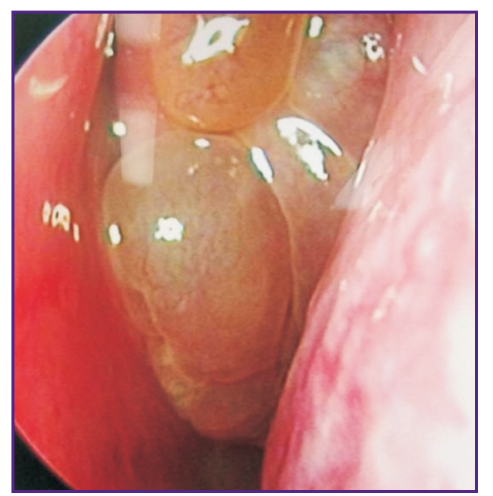

Figure 1. An intraoperative fragment of video rhinoendoscopy. Patient L., 38 years, diagnosis: "polypous rhinosinusitis, aspirin triad"

Multiple dense polypous overgrowths in the middle nasal passage are seen, the process involves the common nasal passage
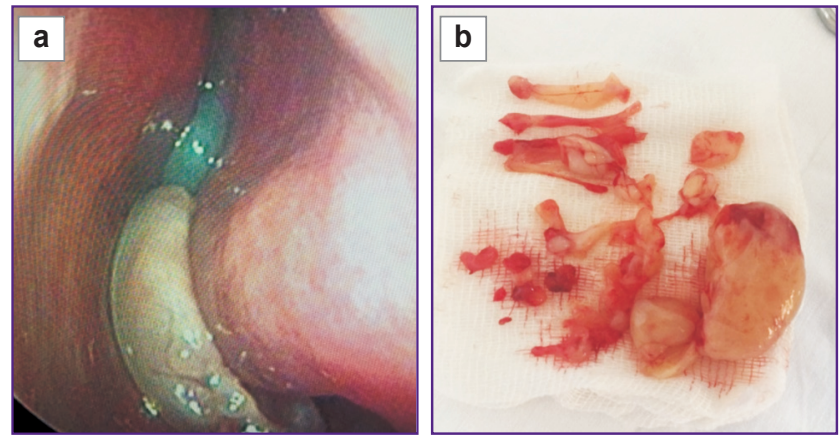

Figure 2. An intraoperative fragment of video rhinoendoscopy. Patient V., 26 years, diagnosis: "polypous hemisinusitis concurrent with bronchial asthma":

(a) loose polypous overgrowths in the posterior parts of the nasal cavity and nasopharynx are seen; the process spreads from the cells of the ethmoidal labyrinth and maxillary sinus; (b) removed polypous fragments

is noted. Perhaps, the original epithelial vulnerability plays a role in this mechanism, leading to submucosal mesenchymal activation. As for the submucosa, the remodeling processes in CRS with polyps and in allergic BA include hypertrophy of the mucous glands and excessive generation of ECM components. However, there are significant differences: pseudocysts in the nasal and paranasal mucous membranes are observed only in patients with CRS with polyps, but not in the mucous membrane of the lower airways in asthma [5].

\section{Conclusion}

According to the current concepts, the extracellular matrix is a biologically active medium that impacts the course and outcome of diseases. The restructuring (or remodeling) of the extracellular matrix is a pathogenetic mechanism that underlies a number of clinical conditions, including bronchial asthma and concomitant diseases of the upper airway.

Airway remodeling is characteristic of bronchial asthma; it starts at early stages of the disease and may reflect previous life events and/or persistent airway inflammation. The restructuring of the extracellular matrix in patients with asthma is an active and very complex process involving multicomponent changes in the lower airway, such as epithelial desquamation, hyperplasia of the goblet cells, thickening of the basement membrane, subepithelial fibrosis, hyperplasia of smooth muscles of the bronchi, and increased angiogenesis.

At the same time, in patients with asthma combined with isolated allergic rhinitis, the remodeling is limited just to thickening of the basement membranes despite the severe Th2-dependent mucosa inflammation.

However, some patients demonstrate hyperplasia of the nasal mucosa, which apparently leads to the development of chronic rhinosinusitis with or without polyps. These processes are characterized by gross 
changes in the extracellular matrix, which are yet to be specified.

With regard to the pathological processes caused by the extracellular matrix remodeling, an efficient therapeutic approach is yet to be proposed. Further research into the tissue remodeling in the upper and lower airways in patients with bronchial asthma and concomitant upper airway diseases is needed to elucidate their pathogeneses and develop therapeutic strategies for the treatment of allergic diseases and clinical consequences of airway remodeling.

Research funding. The study was not funded by any external source.

Conflict of interest. The authors have no conflicts of interest.

\section{References}

1. Theocharis A.D., Skandalis S.S., Gialeli C., Karamanos N.K. Extracellular matrix structure. Adv Drug Deliv Rev 2016; 97: 4-27, https://doi.org/10.1016/j.addr.2015.11.001.

2. LeMessurier K.S., Palipane M., Tiwary M., Gavin B., Samarasinghe A.E. Chronic features of allergic asthma are enhanced in the absence of resistin-like molecule-beta. Sci Rep 2018; 8(1): 7061, https://doi.org/10.1038/s41598-01825321-y.

3. Gu B.H., Madison M.C., Corry D., Kheradmand F. Matrix remodeling in chronic lung diseases. Matrix Biol 2018, 73: 52-63, https://doi.org/10.1016/j.matbio.2018.03.012.

4. Annoni R., Lancas T., Yukimatsu Tanigawa R., de Medeiros Matsushita M., de Morais Fernezlian S., Bruno A., Fernando Ferraz da Silva L., Roughley P.J., Battaglia S., Dolhnikoff M., Hiemstra P.S., Sterk P.J., Rabe K.F., Mauad T. Extracellular matrix composition in COPD. Eur Respir J 2012; 40(6): 1362-1373, https://doi. org/10.1183/09031936.00192611.

5. Samitas K., Carter A., Kariyawasam H.H., Xanthou G. Upper and lower airway remodelling mechanisms in asthma, allergic rhinitis and chronic rhinosinusitis: the one airway concept revisited. Allergy 2018; 73(5): 993-1002, https://doi. org/10.1111/all.13373.

6. Weitoft M., Andersson C., Andersson-Sjoland A., Tufvesson E., Bjermer L., Erjefalt J., Westergren-Thorsson G. Controlled and uncontrolled asthma display distinct alveolar tissue matrix compositions. Respir Res 2014; 15: 67, https:// doi.org/10.1186/1465-9921-15-67.

7. Wight T.N., Frevert C.W., Debley J.S., Reeves S.R., Parks W.C., Ziegler S.F. Interplay of extracellular matrix and leukocytes in lung inflammation. Cell Immunol 2017; 312: 1-14, https://doi.org/10.1016/j.cellimm.2016.12.003.

8. Grzela K., Zagorska W., Krejner A., Litwiniuk M., Zawadzka-Krajewska A., Banaszkiewicz A., Kulus M., Grzela T. Prolonged treatment with inhaled corticosteroids does not normalize high activity of matrix metalloproteinase-9 in exhaled breath condensates of children with asthma. Arch Immunol Ther Exp (Warsz) 2015; 63(3): 231-237, https://doi. org/10.1007/s00005-015-0328-z.

9. Mouw J.K., Ou G., Weaver V.M. Extracellular matrix assembly: a multiscale deconstruction. Nat Rev Mol Cell Biol 2014; 15(12): 771-785, https://doi.org/10.1038/nrm3902.
10. Pozzi A., Yurchenco P.D., lozzo R.V. The nature and biology of basement membranes. Matrix Biol 2017; 57-58: 1-11, https://doi.org/10.1016/j.matbio.2016.12.009.

11. Hohenester E., Yurchenco P.D. Laminins in basement membrane assembly. Cell Adh Migr 2013; 7(1): 56-63, https:// doi.org/10.4161/cam.21831.

12. Timpl R., Brown J.C. Supramolecular assembly of basement membranes. Bioessays 1996; 18(2): 123-132, https://doi.org/10.1002/bies.950180208.

13. Dziadek M. Role of laminin-nidogen complexes in basement membrane formation during embryonic development. Experientia 1995; 51(9-10): 901-913, https:// doi.org/10.1007/bf01921740.

14. Sonbol H.S. Extracellular matrix remodeling in human disease. J Microsc Ultrastruct 2018; 6(3): 123-128, https://doi. org/10.4103/jmau.jmau_4_18.

15. LeBleu V.S., Macdonald B., Kalluri R. Structure and function of basement membranes. Exp Biol Med (Maywood) 2007; 232(9): 1121-1129, https://doi.org/10.3181/0703-mr-72.

16. Halfter W., Oertle P., Monnier C.A., Camenzind L., Reyes-Lua M., Hu H., Candiello J., Labilloy A., Balasubramani M., Henrich P.B., Plodinec M. New concepts in basement membrane biology. FEBS J 2015; 282(23): 44664479, https://doi.org/10.1111/febs.13495.

17. Behrens D.T., Villone D., Koch M., Brunner G., Sorokin L., Robenek H., Bruckner-Tuderman L., Bruckner P., Hansen $U$. The epidermal basement membrane is a composite of separate laminin- or collagen IV-containing networks connected by aggregated perlecan, but not by nidogens. $J$ Biol Chem 2012; 287(22): 18700-18709, https://doi.org/10.1074/ jbc.M111.336073.

18. Fernandes D.J., Bonacci J.V., Stewart A.G. Extracellular matrix, integrins, and mesenchymal cell function in the airways. Curr Drug Targets 2006; 7(5): 567-577.

19. Hansen S.W., Ohtani K., Roy N., Wakamiya N. The collectins CL-L1, CL-K1 and CL-P1, and their roles in complement and innate immunity. Immunobiology 2016; 221(10): 1058-1067, https://doi.org/10.1016/j.imbio.2016.05.012.

20. Kubysheva N., Soodaeva S., Novikov V., Eliseeva T., Li T., Klimanov I., Kuzmina E., Baez-Medina H., Solovyev V., Ovsyannikov D.Y., Batyrshin I. Soluble HLA-I and HLA-II molecules are potential prognostic markers of progression of systemic and local inflammation in patients with COPD. Disease Markers 2018; 2018: 1-7, https://doi.org/https://doi. org/10.1155/2018/3614341.

21. Barnes P.J. Cellular and molecular mechanisms of asthma and COPD. Clin Sci (Lond) 2017; 131(13): 1541-1558, https://doi.org/10.1042/CS20160487.

22. Burgess J.K., Ceresa C., Johnson S.R., Kanabar V., Moir L.M., Nguyen T.T., Oliver B.G., Schuliga M., Ward J. Tissue and matrix influences on airway smooth muscle function. Pulm Pharmacol Ther 2009; 22(5): 379-387, https:// doi.org/10.1016/j.pupt.2008.12.007.

23. Sapir L., Tzlil S. Talking over the extracellular matrix: how do cells communicate mechanically? Semin Cell Dev Biol 2017; 71: 99-105, https://doi.org/10.1016/j.semcdb.2017.06.010.

24. Wells J.M., Gaggar A., Blalock J.E. MMP generated matrikines. Matrix Biol 2015; 44-46: 122-129, https://doi. org/10.1016/j.matbio.2015.01.016.

25. Ricard-Blum S., Salza R. Matricryptins and matrikines: biologically active fragments of the extracellular matrix. Exp Dermatol 2014; 23(7): 457-463, https://doi.org/10.1111/ exd.12435. 
26. Jarvelainen $H_{\text {., }}$ Sainio A., Koulu M., Wight T.N., Penttinen R. Extracellular matrix molecules: potential targets in pharmacotherapy. Pharmacol Rev 2009; 61(2): 198-223, https://doi.org/10.1124/pr.109.001289.

27. Burgess J.K., Mauad T., Tjin G., Karlsson J.C., Westergren-Thorsson $\mathrm{G}$. The extracellular matrix - the underrecognized element in lung disease? J Pathol 2016; 240(4): 397-409, https://doi.org/10.1002/path.4808.

28. Liu G., Cooley M.A., Nair P.M., Donovan C., Hsu A.C., Jarnicki A.G., Haw T.J., Hansbro N.G., Ge Q., Brown A.C., Tay H., Foster P.S., Wark P.A., Horvat J.C., Bourke J.E., Grainge C.L., Argraves W.S., Oliver B.G., Knight D.A., Burgess J.K., Hansbro P.M. Airway remodelling and inflammation in asthma are dependent on the extracellular matrix protein fibulin-1c. J Pathol 2017; 243(4): 510-523, https://doi.org/10.1002/path.4979.

29. White E.S. Lung extracellular matrix and fibroblast function. Ann Am Thorac Soc 2015; 12(Suppl 1): S30-S33, https://doi.org/10.1513/annalsats.201406-240mg.

30. Pawankar R., Nonaka M. Inflammatory mechanisms and remodeling in chronic rhinosinusitis and nasal polyps. Curr Allergy Asthma Rep 2007; 7(3): 202-208.

31. Watelet J.B., Dogne J.M., Mullier F. Remodeling and repair in rhinosinusitis. Curr Allergy Asthma Rep 2015; 15(6): 34, https://doi.org/10.1007/s11882-015-0531-3.

32. Boulet L.P. Airway remodeling in asthma: update on mechanisms and therapeutic approaches. Curr Opin Pulm Med 2018; 24(1): 56-62, https://doi.org/10.1097/ MCP.0000000000000441.

33. Bonnans C., Chou J., Werb Z. Remodelling the extracellular matrix in development and disease. Nat Rev Mol Cell Biol 2014; 15(12): 786-801, https://doi.org/10.1038/ nrm3904.

34. Cox T.R., Erler J.T. Remodeling and homeostasis of the extracellular matrix: implications for fibrotic diseases and cancer. Dis Model Mech 2011; 4(2): 165-178, https://doi. org/10.1242/dmm.004077.

35. Smith H.W., Marshall C.J. Regulation of cell signalling by uPAR. Nat Rev Mol Cell Biol 2010; 11(1): 23-36, https://doi. org/10.1038/nrm2821.

36. Giuffrida P., Biancheri P., MacDonald T.T. Proteases and small intestinal barrier function in health and disease. Curr Opin Gastroenterol 2014; 30(2): 147-153, https://doi. org/10.1097/MOG.0000000000000042.

37. Rawlings N.D., Waller M., Barrett A.J., Bateman A. MEROPS: the database of proteolytic enzymes, their substrates and inhibitors. Nucleic Acids Res 2014; 42(D1): D503-D509, https://doi.org/10.1093/nar/gkt953.

38. Murphy G. Riding the metalloproteinase roller coaster. J Biol Chem 2017; 292(19): 7708-7718, https://doi. org/10.1074/jbc.x117.785295.

39. Jones G.C., Riley G.P. ADAMTS proteinases: a multidomain, multi-functional family with roles in extracellular matrix turnover and arthritis. Arthritis Res Ther 2005; 7(4): 160-169, https://doi.org/10.1186/ar1783.

40. Krouse J.H. Asthma management for the otolaryngologist. Otolaryngol Clin North Am 2017; 50(6): 10651076, https://doi.org/10.1016/j.otc.2017.08.006.

41. Broder C., Arnold P., Vadon-Le Goff S., Konerding M.A., Bahr K., Muller S., Overall C.M., Bond J.S., Koudelka T., Tholey A., Hulmes D.J., Moali C., Becker-Pauly C. Metalloproteases meprin alpha and meprin beta are C- and $\mathrm{N}$-procollagen proteinases important for collagen assembly and tensile strength. Proc Natl Acad Sci USA 2013; 110(35): 14219-14224, https://doi.org/10.1073/pnas.1305464110.

42. Prakash Y.S. Airway smooth muscle in airway reactivity and remodeling: what have we learned? Am J Physiol Lung Cell Mol Physiol 2013; 305(12): L912-L933, https://doi. org/10.1152/ajplung.00259.2013.

43. Al-Muhsen S., Johnson J.R., Hamid Q. Remodeling in asthma. J Allergy Clin Immunol 2011; 128(3): 451-462, https:// doi.org/10.1016/j.jaci.2011.04.047.

44. Tschumperlin D.J. Physical forces and airway remodeling in asthma. N Engl J Med 2011; 364(21): 20582059, https://doi.org/10.1056/NEJMe1103121.

45. Fehrenbach H., Wagner C., Wegmann M. Airway remodeling in asthma: what really matters. Cell Tissue Res 2017; 367(3): 551-569, https://doi.org/10.1007/s00441-0162566-8.

46. Payne D.N., Rogers A.V., Adelroth E., Bandi V., Guntupalli K.K., Bush A., Jeffery P.K. Early thickening of the reticular basement membrane in children with difficult asthma. Am J Respir Crit Care Med 2003; 167(1): 78-82, https://doi. org/10.1164/rccm.200205-414oc.

47. Pohunek P., Warner J.O., Turzikova J., Kudrmann J., Roche W.R. Markers of eosinophilic inflammation and tissue re-modelling in children before clinically diagnosed bronchial asthma. Pediatr Allergy Immunol 2005; 16(1): 43-51, https:// doi.org/10.1111/j.1399-3038.2005.00239.x.

48. Elliot J.G., Noble P.B., Mauad T., Bai T.R., Abramson M.J., McKay K.O., Green F.H.Y., James A.L. Inflammation-dependent and independent airway remodelling in asthma. Respirology 2018; 23(12): 1138-1145, https://doi. org/10.1111/resp.13360.

49. Kicic A., Sutanto E.N., Stevens P.T., Knight D.A., Stick S.M. Intrinsic biochemical and functional differences in bronchial epithelial cells of children with asthma. Am J Respir Crit Care Med 2006; 174(10): 1110-1118, https://doi. org/10.1164/rccm.200603-392oc.

50. James A.L., Bai T.R., Mauad T., Abramson M.J., Dolhnikoff M., McKay K.O., Maxwell P.S., Elliot J.G., Green F.H. Airway smooth muscle thickness in asthma is related to severity but not duration of asthma. Eur Respir J 2009; 34(5): 1040-1045, https://doi.org/10.1183/09031936.00181608.

51. Prakash Y.S., Halayko A.J., Gosens R., Panettieri R.A. Jr., Camoretti-Mercado B., Penn R.B. An official American Thoracic Society research statement: current challenges facing research and therapeutic advances in airway remodeling. Am J Respir Crit Care Med 2017; 195(2): e4-e19, https://doi.org/10.1164/rccm.201611-2248st.

52. Huber H.L., Koessler K.K. The pathology of bronchial asthma. Arch Intern Med 1922; 30(6): 689-760, https://doi. org/10.1001/archinte.1922.00110120002001.

53. Pascoe C.D., Seow C.Y., Hackett T.L., Pare P.D., Donovan G.M. Heterogeneity of airway wall dimensions in humans: a critical determinant of lung function in asthmatics and nonasthmatics. Am J Physiol Lung Cell Mol Physiol 2017; 312(3): L425-L431, https://doi.org/10.1152/ ajplung.00421.2016.

54. Poon A.H., Hamid Q. Severe asthma: have we made progress? Ann Am Thorac Soc 2016; 13(Suppl 1): S68-S77.

55. Huang J., Olivenstein R., Taha R., Hamid Q., Ludwig M. Enhanced proteoglycan deposition in the airway wall of atopic asthmatics. Am J Respir Crit Care Med 1999; 160(2): 725-729, https://doi.org/10.1164/ajrccm.160.2.9809040.

56. Ward C., Reid D.W., Orsida B.E., Feltis B., Ryan V.A., 
Johns D.P., Walters E.H. Inter-relationships between airway inflammation, reticular basement membrane thickening and bronchial hyper-reactivity to methacholine in asthma; a systematic bronchoalveolar lavage and airway biopsy analysis. Clin Exp Allergy 2005; 35(12): 1565-1571, https://doi. org/10.1111/j.1365-2222.2005.02365.x.

57. Davies D.E. The role of the epithelium in airway remodeling in asthma. Proc Am Thorac Soc 2009; 6(8): 678682, https://doi.org/10.1513/pats.200907-067dp.

58. Holgate S.T., Wenzel S., Postma D.S., Weiss S.T., Renz H., Sly P.D. Asthma. Nat Rev Dis Primers 2015; 1: 15025, https://doi.org/10.1038/nrdp.2015.25.

59. Holgate S.T. Mechanisms of asthma and implications for its prevention and treatment: a personal journey. Allergy Asthma Immunol Res 2013; 5(6): 343-347, https://doi. org/10.4168/aair.2013.5.6.343.

60. Nayak A.P., Deshpande D.A., Penn R.B. New targets for resolution of airway remodeling in obstructive lung diseases. F1000Res 2018; 7: 680, https://doi.org/10.12688/ f1000research.14581.1.

61. Chan V., Burgess J.K., Ratoff J.C., O'Connor B.J., Greenough A., Lee T.H., Hirst S.J. Extracellular matrix regulates enhanced eotaxin expression in asthmatic airway smooth muscle cells. Am J Respir Crit Care Med 2006; 174(4): 379-385, https://doi.org/10.1164/rccm.200509-1420oc.

62. Lauzon A.M., Martin J.G. Airway hyperresponsiveness; smooth muscle as the principal actor. F1000Res 2016; 5: 306, https://doi.org/10.12688/f1000research.7422.1.

63. Grainge C.L., Lau L.C., Ward J.A., Dulay V., Lahiff G., Wilson S., Holgate S., Davies D.E., Howarth P.H. Effect of bronchoconstriction on airway remodeling in asthma. $N$ Engl J Med 2011; 364(21): 2006-2015, https://doi.org/10.1056/ nejmoa1014350.

64. Gosens R., Grainge C. Bronchoconstriction and airway biology: potential impact and therapeutic opportunities. Chest 2015; 147(3): 798-803, https://doi.org/10.1378/ chest.14-1142.

65. Dogan M., Han Y.S., Delmotte P., Sieck G.C. TNFalpha enhances force generation in airway smooth muscle. Am J Physiol Lung Cell Mol Physiol 2017; 312(6): L994-L1002, https://doi.org/10.1152/ajplung.00550.2016.

66. Burgess J.K., Ge Q., Boustany S., Black J.L., Johnson P.R. Increased sensitivity of asthmatic airway smooth muscle cells to prostaglandin E2 might be mediated by increased numbers of E-prostanoid receptors. J Allergy Clin Immunol 2004; 113(5): 876-881, https://doi.org/10.1016/j. jaci.2004.02.029.

67. Brightling C.E., Bradding P. The re-emergence of the mast cell as a pivotal cell in asthma pathogenesis. Curr Allergy Asthma Rep 2005; 5(2): 130-135, https://doi.org/10.1007/ s11882-005-0086-9.

68. Niimi A., Matsumoto H., Amitani R., Nakano Y., Sakai H., Takemura M., Ueda T., Chin K., Itoh H., Ingenito E.P., Mishima M. Effect of short-term treatment with inhaled corticosteroid on airway wall thickening in asthma. Am J Med 2004; 116(11): 725731, https://doi.org/10.1016/j.amjmed.2003.11.026.

69. Walker J.K.L., Theriot B.S., Ghio M., Trempus C.S., Wong J.E., McQuade V.L., Liang J., Jiang D., Noble P.W., Garantziotis S., Kraft M., Ingram J.L. Targeted HAS2 expression lessens airway responsiveness in chronic murine allergic airway disease. Am J Respir Cell Mol Biol 2017; 57(6): 702-710, https://doi.org/10.1165/rcmb.2017-0095oc.

70. Kruse M.N., Becker C., Lottaz D., Köhler D.,
Yiallouros I., Krell H.W., Sterchi E.E., Stöcker W. Human meprin alpha and beta homo-oligomers: cleavage of basement membrane proteins and sensitivity to metalloprotease inhibitors. Biochem J 2004; 378(Pt 2): 383-389, https://doi. org/10.1042/bj20031163.

71. Bougault V., Loubaki L., Joubert P., Turmel J., Couture C., Laviolette M., Chakir J., Boulet L.P. Airway remodeling and inflammation in competitive swimmers training in indoor chlorinated swimming pools. J Allergy Clin Immunol 2012; 129(2): 351-358.e1, https://doi.org/10.1016/j.jaci.2011.11.010.

72. ten Brinke A. Risk factors associated with irreversible airflow limitation in asthma. Curr Opin Allergy Clin Immunol 2008; 8(1): 63-69, https://doi.org/10.1097/ aci.0b013e3282f3b5b5.

73. Lange P., Parner J., Vestbo J., Schnohr P., Jensen G. A 15-year follow-up study of ventilatory function in adults with asthma. N Engl J Med 1998; 339(17): 1194-1200, https://doi. org/10.1056/nejm199810223391703.

74. Niimi A., Matsumoto H., Takemura M., Ueda T., Chin K., Mishima M. Relationship of airway wall thickness to airway sensitivity and airway reactivity in asthma. Am J Respir Crit Care Med 2003; 168(8): 983-988, https://doi.org/10.1164/ rccm.200211-1268oc.

75. McParland B.E., Macklem P.T., Pare P.D. Airway wall remodeling: friend or foe? J Appl Physiol 2003; 95(1): 426434, https://doi.org/10.1152/japplphysiol.00159.2003.

76. Lezmi G., Gosset P., Deschildre A., Abou-Taam R., Mahut B., Beydon N., de Blic J. Airway Remodeling in preschool children with severe recurrent wheeze. Am J Respir Crit Care Med 2015; 192(2): 164-171, https://doi.org/10.1164/ rccm.201411-1958oc.

77. Chakir J., Laviolette M., Boutet M., Laliberté R., Dubé J., Boulet L.P. Lower airways remodeling in nonasthmatic subjects with allergic rhinitis. Lab Invest 1996; 75(5): 735-744.

78. Tillie-Leblond I., de Blic J., Jaubert F., Wallaert B., Scheinmann P., Gosset P. Airway remodeling is correlated with obstruction in children with severe asthma. Allergy 2008; 63(5): 533-541, https://doi.org/10.1111/j.1398-9995.2008.01656.x.

79. O'Reilly R., Ullmann N., Irving S., Bossley C.J., Sonnappa S., Zhu J., Oates T., Banya W., Jeffery P.K., Bush A., Saglani S. Increased airway smooth muscle in preschool wheezers who have asthma at school age. J Allergy Clin Immunol 2013; 131(4): 1024-1032.e16, https://doi. org/10.1016/j.jaci.2012.08.044.

80. Owens L., Laing I.A., Zhang G., Le Souef P.N. Infant lung function predicts asthma persistence and remission in young adults. Respirology 2017; 22(2): 289-294, https://doi. org/10.1111/resp.12901.

81. Williams R.C., Skelton A.J., Todryk S.M., Rowan A.D. Preshaw P.M., Taylor J.J. Leptin and pro-inflammatory stimuli synergistically upregulate MMP-1 and MMP-3 secretion in human gingival fibroblasts. PLoS One 2016; 11(2): e0148024, https://doi.org/10.1371/journal.pone.0148024.

82. Sicard D., Haak A.J., Choi K.M., Craig A.R., Fredenburgh L.E., Tschumperlin D.J. Aging and anatomical variations in lung tissue stiffness. Am J Physiol Lung Cell Mol Physiol 2018; 314(6): L946-L955, https://doi.org/10.1152/ ajplung.00415.2017.

83. Russell R.E., Culpitt S.V., DeMatos C., Donnelly L., Smith M., Wiggins J., Barnes P.J. Release and activity of matrix metalloproteinase- 9 and tissue inhibitor of metalloproteinase- 1 by alveolar macrophages from patients with chronic obstructive pulmonary disease. Am J Respir 
Cell Mol Biol 2002; 26(5): 602-609, https://doi.org/10.1165/ ajrcmb.26.5.4685.

84. Todorova L., Gurcan E., Miller-Larsson A., WestergrenThorsson G. Lung fibroblast proteoglycan production induced by serum is inhibited by budesonide and formoterol. Am J Respir Cell Mol Biol 2006; 34(1): 92-100, https://doi. org/10.1165/rcmb.2005-0048oc.

85. Eliseeva T.I., Geppe N.A., Tush E.V., Khaletskaya O.V., Balabolkin I.I., Bulgakova V.A., Kubysheva N.I., Ignatov S.K. Body height of children with bronchial asthma of various severities. Can Respir J 2017; 2017: 8761404, https://doi. org/10.1155/2017/8761404.

86. Eliseeva T.I., Geppe N.A., Ignatov S.K., Soodaeva S.K., Tush E.V., Khaletskaya O.V., Potemina T.E., Malakhov A.B., Kubysheva N.I., Solovyov V.A. Relative body mass index as a new tool for nutritional status assessment in children and adolescents with bronchial asthma. Sovremennye tehnologii $v$ medicine 2017; 9(1): 135-148, https://doi.org/10.17691/ stm2017.9.1.18.

87. Tushch E.V., Eliseeva T.I., Balabolkin I.I., Bulgakova V.A., Khaletskaya O.V., Shchukina D.A., Romanova N.V., Malyshev I.S., Kuzmichev K.V., Potemina T.E., Novikova N.A., Prakhov A.V. Peculiarities of physical development of children and adolescents having bronchial asthma. Medicinskij al'manah 2017; (2): 52-56, https://doi.org/10.21145/2499-9954-2017-252-56.

88. Zhang Z., Wang F., Wang B.J., Chu G., Cao Q., Sun B.G., Dai Q.Y. Inhibition of leptin-induced vascular extracellular matrix remodelling by adiponectin. $J \mathrm{Mo}$ Endocrinol 2014; 53(2): 145-154, https://doi.org/10.1530/jme14-0027.

89. Arteaga-Solis E., Zee T., Emala C.W., Vinson C., Wess J., Karsenty G. Inhibition of leptin regulation of parasympathetic signaling as a cause of extreme body weightassociated asthma. Cell Metab 2013; 17(1): 35-48, https://doi. org/10.1016/j.cmet.2012.12.004.

90. Deshpande M., Papp S., Schaffer L., Pouyani T. Hydrocortisone and triiodothyronine regulate hyaluronate synthesis in a tissue-engineered human dermal equivalent through independent pathways. J Biosci Bioeng 2015; 119(2): 226-236, https://doi.org/10.1016/j.jbiosc.2014.08.001.

91. Cayrol F., Diaz Flaque M.C., Fernando T., Yang S.N., Sterle H.A., Bolontrade M., Amoros M., Isse B., Farias R.N., Ahn H., Tian Y.F., Tabbo F., Singh A., Inghirami G., Cerchietti L., Cremaschi G.A. Integrin alphavbeta3 acting as membrane receptor for thyroid hormones mediates angiogenesis in malignant T cells. Blood 2015; 125(5): 841-851, https://doi. org/10.1182/blood-2014-07-587337.

92. Wenzel S.E., Robinson C.B., Leonard J.M., Panettieri R.A. Jr. Nebulized dehydroepiandrosterone-3-sulfate improves asthma control in the moderate-to-severe asthma results of a 6-week, randomized, double-blind, placebocontrolled study. Allergy Asthma Proc 2010; 31(6): 461-471, https://doi.org/10.2500/aap.2010.31.3384.

93. Nair P., Radford K., Fanat A., Janssen L.J., PetersGolden M., Cox P.G. The effects of leptin on airway smooth muscle responses. Am J Respir Cell Mol Biol 2008; 39(4): 475-481, https://doi.org/10.1165/rcmb.2007-0091oc.

94. Gupta A., Sjoukes A., Richards D., Banya W., Hawrylowicz C., Bush A., Saglani S. Relationship between serum vitamin $D$, disease severity, and airway remodeling in children with asthma. Am J Respir Crit Care Med 2011; 184(12): 1342-1349, https://doi.org/10.1164/rccm.201107-1239oc.
95. Gosens R., Nelemans S.A., Hiemstra M., Grootte Bromhaar M.M., Meurs H., Zaagsma J. Insulin induces a hypercontractile airway smooth muscle phenotype. Eur $J$ Pharmacol 2003; 481(1): 125-131, https://doi.org/10.1016/j. ejphar.2003.08.081.

96. Degano B., Mourlanette P., Valmary S., Pontier S., Prevost M.C., Escamilla R. Differential effects of low and highdose estradiol on airway reactivity in ovariectomized rats. Respir Physiol Neurobiol 2003; 138(2-3): 265-274, https://doi. org/10.1016/j.resp.2003.08.007.

97. Carlson C.L., Cushman M., Enright P.L., Cauley J.A., Newman A.B. Hormone replacement therapy is associated with higher FEV1 in elderly women. Am J Respir Crit Care Med 2001; 163(2): 423-428, https://doi.org/10.1164/ ajrccm.163.2.2003040.

98. Montaño L.M., Espinoza J., Flores-Soto E., Chávez J., Perusquía M. Androgens are bronchoactive drugs that act by relaxing airway smooth muscle and preventing bronchospasm. $J$ Endocrinol 2014; 222(1): 1-13, https://doi.org/10.1530/joe14-0074.

99. Bordallo J., de Boto M.J., Meana C., Velasco L., Bordallo C., Suárez L., Cantabrana B., Sánchez M. Modulatory role of endogenous androgens on airway smooth muscle tone in isolated guinea-pig and bovine trachea; involvement of beta2-adrenoceptors, the polyamine system and external calcium. Eur J Pharmacol 2008; 601(1-3): 154-162, https://doi. org/10.1016/j.ejphar.2008.10.039.

100. Ishida-Takahashi R., Uotani S., Abe T., DegawaYamauchi M., Fukushima T., Fujita N., Sakamaki H., Yamasaki H., Yamaguchi Y., Eguchi K. Rapid inhibition of leptin signaling by glucocorticoids in vitro and in vivo. $\mathrm{J}$ Biol Chem 2004; 279(19): 19658-19664, https://doi.org/10.1074/jbc. m310864200.

101. Kistemaker L.E., Oenema T.A., Meurs H., Gosens R. Regulation of airway inflammation and remodeling by muscarinic receptors: perspectives on anticholinergic therapy in asthma and COPD. Life Sci 2012; 91(21-22): 1126-1133, https://doi.org/10.1016/j.lfs.2012.02.021.

102. Matthiesen S., Bahulayan A., Kempkens S., Haag S., Fuhrmann M., Stichnote C., Juergens U.R., Racke K. Muscarinic receptors mediate stimulation of human lung fibroblast proliferation. Am J Respir Cell Mol Biol 2006; 35(6): 621-627, https://doi.org/10.1165/rcmb.2005-0343rc.

103. Haag S., Matthiesen S., Juergens U.R., Racke K. Muscarinic receptors mediate stimulation of collagen synthesis in human lung fibroblasts. Eur Respir J 2008; 32(3): 555-562, https://doi.org/10.1183/09031936.00129307.

104. Jia Y., Yue Y., Hu D.N., Chen J.L., Zhou J.B. Human aqueous humor levels of transforming growth factor-beta2: association with matrix metalloproteinases/tissue inhibitors of matrix metalloproteinases. Biomed Rep 2017; 7(6): 573-578, https://doi.org/10.3892/br.2017.1004

105. Eliseeva T.I., Balabolkin I.I. Modern technologies of bronchial asthma control in children (review). Sovremennye tehnologii $v$ medicine 2015; 7(2): 168-184, https://ddoi. org/10.17691/stm2015.7.2.21

106. Buels K.S., Jacoby D.B., Fryer A.D. Nonbronchodilating mechanisms of tiotropium prevent airway hyperreactivity in a guinea-pig model of allergic asthma. $\mathrm{Br} \mathrm{J}$ Pharmacol 2012; 165(5): 1501-1514, https://doi.org/10.1111/ j.1476-5381.2011.01632.x.

107. Asano K., Shikama Y., Shoji N., Hirano K., Suzaki H., Nakajima H. Tiotropium bromide inhibits TGF-beta-induced 
MMP production from lung fibroblasts by interfering with Smad and MAPK pathways in vitro. Int J Chron Obstruct Pulmon Dis 2010; 5: 277-286, https://doi.org/10.2147/copd.s11737.

108. Pera T., Zuidhof A., Valadas J., Smit M., Schoemaker R.G., Gosens R., Maarsingh H., Zaagsma J., Meurs $\mathrm{H}$. Tiotropium inhibits pulmonary inflammation and remodelling in a guinea pig model of COPD. Eur Respir J 2011; 38(4): 789-796, https://doi.org/10.1183/09031936.00146610.

109. Bousquet J., Arnavielhe S., Bedbrook A., Fonseca J., Morais Almeida M., Todo Bom A., Annesi-Maesano I., Caimmi D., Demoly P., Devillier P., Siroux V., Menditto E., Passalacqua G., Stellato C., Ventura M.T., Cruz A.A., Sarquis Serpa F., da Silva J., Larenas-Linnemann D., Rodriguez Gonzalez M., Burguete Cabanas M.T., Bergmann K.C., Keil T., Klimek L., Mosges R., Shamai S., Zuberbier T., Bewick M., Price D., Ryan D., Sheikh A., Anto J.M., Mullol J., Valero A., Haahtela T., Valovirta E., Fokkens W.J., Kuna P., Samolinski B., Bindslev-Jensen C., Eller E., Bosnic-Anticevich S., O'Hehir R.E., Tomazic P.V., Yorgancioglu A., Gemicioglu B., Bachert C., Hellings P.W., Kull I., Melen E., Wickman M., van Eerd M., De Vries G. The Allergic Rhinitis and its Impact on Asthma (ARIA) score of allergic rhinitis using mobile technology correlates with quality of life: the MASK study. Allergy 2018; 73(2): 505-510, https:// doi.org/10.1111/all.13307.

110. Krasilnikova S.V., Eliseeva T.I., Popov K.S., Tush E.V., Khaletskaya O.V., Ovsyannikov D.Y., Balabolkin I.I., Shakhov A.V., Prahov A.V. Multimorbidity of upper respiratory tract pathology in children with bronchial asthma. Pediatria 2018; 97(2): 19-26, https://doi.org/10.24110/0031403X-2018-97-2-19-26.

111. Krasilnikova S.V., Eliseeva T.I., Shakhov A.V., Geppe N.A. Capabilities of nasal videoendoscopy in diagnostics of pharyngeal tonsil condition in children with bronchial asthma. Sovremennye tehnologii v medicine 2016; 8(3): 126-136, https://doi.org/10.17691/stm2016.8.3.15.

112. Eliseeva T.I., Krasilnikova S.V., Babaev S.Y., Novozhilov A.A., Ovsyannikov D.Y., Ignatov S.K., Kubysheva N.I., Shakhov A.V. Dependence of anterior active rhinomanometry indices on nasal obstructive disorders in children with atopic bronchial asthma complicated by nasal symptoms. BioMed Research International 2018; 2018: 1-10, https://doi.org/10.1155/2018/1869613.

113. Eliseeva T.I., Krasilnikova S.V., Geppe N.A., Babaev S.Y., Tush E.V., Khaletskaya O.V., Ovsyannikov D.Y., Balabolkin 1.I., Ignatov S.K., Kubysheva N.I. Effect of nasal obstructive disorders on sinonasal symptoms in children with different levels of bronchial asthma control. Canadian Respiratory Journal 2018; 2018, https://doi.org/https://doi. org/10.1155/2018/4835823.

114. Krasilnikova S.V., tush E.V., Babaev S.Y., Khaletskaya A.I., Popov K.S., Novozhilov A.A., Abubakirov T.E., Eliseeva T.I. Ignatov S.K., Shakhov A.V., Kubysheva N.I., Solovyev V.D. Endonasal infrared thermometry for the diagnosis of allergic inflammation of the nasal mucosa in patients with bronchial asthma. Sovremennye tehnologii v medicine 2017; 9(4): 201, https://doi.org/10.17691/stm2017.9.4.25.

115. Bhimrao S.K. Wilson S.J., Howarth P.H. Airway inflammation in atopic patients. a comparison of the upper and lower airways. Otolaryngol Head Neck Surg 2011; 145(3): 396-400, https://doi.org/10.1177/0194599811410531.

116. Lim M.C., Taylor R.M., Naclerio R.M. The histology of allergic rhinitis and its comparison to cellular changes in nasal lavage. Am J Respir Crit Care Med 1995; 151(1): 136-144, https://doi.org/10.1164/ajrccm.151.1.7812543.

117. Eifan A.O., Orban N.T., Jacobson M.R., Durham S.R. Severe persistent allergic rhinitis. Inflammation but no histologic features of structural upper airway remodeling. $\mathrm{Am}$ J Respir Crit Care Med 2015; 192(12): 1431-1439, https://doi. org/10.1164/rccm.201502-0339oc.

118. Krasilnikova S.V., Eliseeva T.I., Shakhov A.V., Prakhov A.V., Balabolkin I.I. Video endoscopic method of estimation state of nasal and pharyngonasal cavity in children with bronchial asthma. Sovremennye tehnologii $v$ medicine 2012; 3: 41-45.

119. Licari A., Caimmi S., Bosa L., Marseglia A., Marseglia G.L., Caimmi D. Rhinosinusitis and asthma: a very long engagement. Int J Immunopathol Pharmacol 2014; 27(4): 499-508, https://doi.org/10.1177/039463201402700405.

120. Licari A., Brambilla I., De Filippo M., Poddighe D., Castagnoli R., Marseglia G.L. The role of upper airway pathology as a co-morbidity in severe asthma. Expert Rev Respir Med 2017; 11(11): 855-865, https://doi.org/10.1080/17 476348.2017.1381564.

121. Fokkens W.J., Lund V.J., Mullol J., Bachert C., Alobid I., Baroody F., Cohen N., Cervin A., Douglas R., Gevaert P., Georgalas C., Goossens H., Harvey R., Hellings P., Hopkins C., Jones N., Joos G., Kalogjera L., Kern B., Kowalski M., Price D., Riechelmann H., Schlosser R., Senior B., Thomas M., Toskala E., Voegels R., Wang de Y., Wormald P.J. EPOS 2012: European position paper on rhinosinusitis and nasal polyps 2012. A summary for otorhinolaryngologists. Rhinology 2012; 50(1): 1-12, https:// doi.org/10.4193/rhino50e2.

122. Rajan J.P., Wineinger N.E., Stevenson D.D., White A.A. Prevalence of aspirin-exacerbated respiratory disease among asthmatic patients: a meta-analysis of the literature. J Allergy Clin Immunol 2015; 135(3): 676-681.e1, https://doi.org/10.1016/j.jaci.2014.08.020.

123. Meng J., Zhou P., Liu Y., Liu F., Yi X., Liu S., Holtappels G., Bachert C., Zhang N. The development of nasal polyp disease involves early nasal mucosal inflammation and remodelling. PLoS One 2013; 8(12): e82373, https://doi. org/10.1371/journal.pone.0082373.

124. Martinez-Anton A., Debolos C., Garrido M., RocaFerrer J., Barranco C., Alobid I., Xaubet A., Picado C., Mullol J. Mucin genes have different expression patterns in healthy and diseased upper airway mucosa. Clin Exp Allergy 2006; 36(4): 448-457, https://doi.org/10.1111/j.13652222.2006.02451.x.

125. Rehl R.M., Balla A.A., Cabay R.J., Hearp M.L., Pytynia K.B., Joe S.A. Mucosal remodeling in chronic rhinosinusitis. Am J Rhinol 2007; 21(6): 651-657, https://doi. org/10.2500/ajr.2007.21.3096.

126. Barham H.P., Osborn J.L., Snidvongs K., Mrad N., Sacks R., Harvey R.J. Remodeling changes of the upper airway with chronic rhinosinusitis. Int Forum Allergy Rhinol 2015; 5(7): 565-572, https://doi.org/10.1002/alr.21546. 